\title{
ANALISIS TINGKAT KEPUASAN KONSUMEN TERHADAP PRODUK KOPI DAN PELAYANAN DI RUMAH KOPI BILLY CABANG MEGAMAS MANADO
}

\author{
Jimmy Rezky Torey \\ Oktavianus Porajouw \\ Tommy F. Lolowang
}

\begin{abstract}
This research aims to measure the level of consumer satisfaction toward coffee products and services in the House Coffee Billy Branches Megamas Manado. The Data used in this research is the primary data. The primary data obtained using the technique of the interview directly to respondents, in this case the consumer products coffee in the coffee House Billy Branches Megamas Manado, using a list of questions (questionnaire) as the tool in data collection. The method used in the sampling is sampling accindental. Analysis of the data that is used is a qualitative descriptive analysis is analyzed using the measurement scale Likert attitude scale installation design and presented using the list of the table and numbers. The results of this research shows that the measurement of the level of consumer satisfaction in the house of coffee Billy Branches Megamas Manado in terms of coffee products and services achieve total score loading data of 2.090 that shows the number of the index measuring consumer satisfaction of $83.6 \%$ and is considered very satisfied. This shows that consumers are very satisfied with the coffee products offered and the services provided by the employees in the House Coffee Billy Branches Megamas Manado and to increase consumer satisfaction in terms of product and services, Coffee House party Billy Branches Megamas Manado must pay attention to the quality of coffee products and quality of service offered. This is very important in order to maintain the customers and get more customers and increase sales
\end{abstract}

Keywords: Consumer Satisfaction, Coffee Products, Sertvices

\begin{abstract}
ABSTRAK
Penelitian ini bertujuan untuk mengukur tingkat kepuasan konsumen terhadap produk kopi dan pelayanan di Rumah Kopi Billy Cabang Megamas Manado. Data yang digunakan dalam penelitian ini adalah data primer. Data primer diperoleh dengan menggunakan teknik wawancara langsung kepada responden, dalam hal ini konsumen produk kopi di Rumah Kopi Billy Cabang Megamas Manado, dengan menggunakan daftar pertanyaan (kuesioner) sebagai alat bantu dalam pengumpulan data. Metode yang digunakan dalam pengambilan sampel adalah accindental sampling. Analisis data yang digunakan merupakan analisis deskriptif kualitatif yang dianalisis dengan menggunakan skala pengukuran sikap Likert Scale dan disajikan menggunakan daftar tabel dan angka. Hasil penelitian ini menunjukan bahwa pengukuran tingkat kepuasan konsumen di Rumah Kopi Billy Cabang Megamas Manado dari segi produk kopi dan pelayanan mencapai total skor pengambilan data sebesar 2.090 yang menunjukan angka indeks pengukuran kepuasan konsumen sebesar $83.6 \%$ dan tergolong sangat puas. Hal ini menunjukan bahwa konsumen sangat puas dengan produk kopi yang ditawarkan dan pelayanan yang diberikan oleh karyawan di Rumah Kopi Billy Cabang Megamas Manado, maka dari itu untuk meningkatkan kepuasan konsumen dari segi produk dan pelayanan, pihak Rumah Kopi Billy Cabang Megamas Manado harus memperhatikan kualitas produk kopi dan kualitas pelayanan yang ditawarkan. Hal ini sangat penting, untuk mempertahankan konsumen dan mendapatkan konsumen lebih banyak serta meningkatkan penjualan
\end{abstract}

Kata kunci: Kepuasan Konsumen, Produk Kopi, Pelayanan 


\section{PENDAHULUAN}

\section{Latar Belakang}

Perkembangan bisnis sekarang ini banyak sekali mengalami kemajuan dan perubahan. Adapun perubahan yang terjadi ditandai dengan kemajuan teknologi, pola pikir masyarakat yang berkembang, dan gaya hidup yang tidak terlepas dari pengaruh globalisasi. Semakin berkembangnya teknologi, pola pikir masyarakat modern, dan perubahan gaya hidup, saat ini seringkali dikaitkan dengan aktivitas masyarakat yang sibuk mengakibatkan orangorang menghabiskan waktu diluar rumah untuk berkumpul, bersantai, bersosialisasi, dan bertukar pikiran.

Menghabiskan waktu diluar rumah bersama keluarga, pasangan, teman ataupun teman kerja tidak terlepas hanya sekedar mengobrol saja, namun sambil menikmati makanan dan minuman. Ini membuat mereka untuk selalu mencari sesuatu yang bersifat praktis dan instan dalam pemenuhan kebutuhan tubuh mereka. Salah satunya mencari makanan dan minuman diluar rumah, hal ini membuat banyaknya berdiri usaha makanan dan minuman yang dimulai dari bisnis makanan berskala kecil seperti warung-warung dan café tenda, bisnis makanan berskala menengah seperti: depot, rumah makan dan café, sampai dengan bisnis makanan yang berskala besar seperti restoranrestoran berbintang.

Semakin meningkatnya bisnis makanan dan minuman dewasa ini, persaingan semakin bertambah ketat. Dalam kondisi persaingan yang semakin ketat setiap perusahaan harus mampu bertahan hidup, bahkan harus dapat berkembang. Setiap perusahaan dituntut untuk memiliki kepekaan terhadap setiap perubahan yang terjadi, dan menempatkan orientasi perasaan senang konsumen sebagai tujuan utama dari perusahaan.

Menurut Umar (2005) mengatakan bahwa kepuasan konsumen merupakan tingkat perasaan seseorang setelah membandingkan antara kinerja produk yang ia rasakan dengan harapannya.

Dalam usaha mencapai kepuasan, konsumen dipengaruhi oleh berbagai macam variabel yang ada pada dirinya sendiri ataupun lingkungannya, dan variabel-variabel tersebut cenderung akan berinteraksi satu dengan lainnya. Rangsangan dari dalam dirinya dapat berupa kebutuhan, keinginan dan karakteristik konsumen. Sedangkan, rangsangan dari luar adalah bagaimana konsumen dapat terpengaruh dengan produk, kualitas pelayanan dan usahausaha pemasaran lain sebagainya.

Menurut Kotler dan Armstrong (1996) produk adalah segala sesuatu yang dapat ditawarkan ke pasar untuk mendapatkan perhatian, dibeli, digunakan atau dikonsumsi yang dapat memuaskan keinginan atau kebutuhan. Ketika konsumen membeli sebuah produk maka konsumen memiliki harapan bagaimana produk tersebut berfungsi, karena sangat berhubungan dengan kesehatan manusia dan merupakan kebutuhan pokok. Maka kualitas produk sangat mempengaruhi konsumen.

Salah satu faktor yang menentukan keberhasilan suatu usaha adalah pelayanan. Kualitas pelayanan sangatlah penting, karena kualitas pelayanan mempengaruhi pelanggan kembali datang atau tidak. Kualitas pelayanan memberikan suatu dorongan kepada konsumen untuk menjalin ikatan hubungan yang kuat dengan perusahaan karena ini mempengaruhi kepuasan konsumen. Kualitas pelayanan juga menjadi salah satu kunci utama keberhasilan dalam mempertahankan pelanggan yang sudah ada. Hal tersebut sepaham dengan pendapat kualitas pelayanan menurut Tjiptono (2007) dimana kualitas pelayanan adalah upaya pemenuhan kebutuhan dan keinginan pelanggan serta ketepatan penyampaiannya untuk mengimbangi harapan pelanggan.

Coffee atau kopi dalam bahasa Indonesia secara luas dikenal sebagai minuman stimulan yang dibuat dari biji kopi. Saat ini kopi adalah salah satu minuman yang paling terkenal di dunia. Tanaman kopi bukan tanaman asli Indonesia, melainkan jenis tanaman yang berasal dari benua Afrika. Tanaman kopi dibawa ke pulau Jawa pada tahun 1696, tetapi pada waktu itu masih dalam taraf percobaan. Di Jawa, tanaman kopi ini mendapat perhatian sepenuhnya baru pada tahun 1699, karena tanaman kopi ini dapat berkembang dan berproduksi dengan baik. Kopi memiliki peranan penting bagi pertumbuhan ekonomi di Indonesia. Indonesia diberkati dengan letak geografisnya yang sangatlah cocok bagi tanaman kopi. Letak Indonesia sangat ideal bagi 
iklim mikro untuk pertumbuhan dan produksi kopi.

Salah satu bisnis yang populer di Indonesia saat ini adalah Coffee Shop. Coffee shop di Indonesia biasa disebut rumah kopi, warung kopi atau kedai kopi. Coffee shop mulai hadir di tengah-tengah kita, mulai dari di pelosok desa, hingga dipusat perkotaan. Kopi merupakan salah satu jenis minuman global yang dicintai oleh sebagian besar umat manusia, kopi dapat dinikmati hampir semua kelompok usia. Mengisi waktu luang sembari menikmati secangkir kopi bersama keluarga, pasangan, teman akrab, ataupun teman kerja sangat menyenangkan. Kopi sangat mudah ditemukan, mulai dari warung pinggir jalan, café, maupun restoran berbintang menyediakan minuman kopi dengan variasi jenis dan harga yang berbeda.

Menikmati kopi saat ini sudah menjadi hal yang biasa ada di kota-kota besar dan di pedesaan. Terlebih menikmati kopi di kedaikedai kopi, rumah kopi, dan restoran berbintang yang ada di sekitar pemukiman penduduk maupun yang berada jauh dari pemukiman penduduk. Kebiasaan masyarakat yang suka meminum kopi ternyata mampu melahirkan peluang bisnis yang menarik dengan keuntungan yang menggiurkan. Dengan meningkatnya konsumsi kopi yang ada pada masyarakat dewasa ini, berdampak terhadap persaingan kedai-kedai kopi, café kopi, dan restoran berbintang yang memang menjual kopi untuk memenuhi kebutuhan konsumen kopi yang semakin beragam.

Di kota Manado, bisnis yang sedang berkembang adalah bisnis Coffee Shop. Perkembangan bisnis Coffee Shop di Manado yang semakin ramai membuat ketatnya persaingan bisnis yang ada, perusahaan dituntut agar bergerak lebih cepat dalam hal menarik konsumen. Sehingga perusahaan perlu mencermati perilaku konsumen dan pelaku bisnis harus mengerti apa yang menjadi kebutuhan dan keinginan konsumen.

Salah satu Coffee Shop yang ada di Manado adalah Rumah Kopi Billy Cabang Megamas atau yang biasa disebut RKB. Coffee Shop ini menawarkan kesan santai, tenang dan nyaman untuk berkumpulnya konsumen dengan keluarga, pasangan, teman, dan teman kerja atau hanya sekedar ingin bersantai menikmati kopi yang disajikan.

Bisnis Coffee Shop ini menawarkan berbagai jenis variasi kopi, kopi yang ditawarkan pun memiliki kualitas produk yang baik, rasa yang enak, dan disajikan dalam bentuk yang menarik, yang dimana mengikuti selera konsumen dan permintaan pasar saat ini. Kebiasaan masyarakat Manado yang suka meminum kopi ini terlihat pada kedai-kedai kopi, rumah kopi, dan bahkan restoran berbintang yang tidak sepi di datangi oleh pembeli, khususnya pecinta kopi.

Rumah Kopi Billy yang terletak di kawasan Megamas Manado tergolong ramai dikunjungi pelanggan. Penulis sering mengunjungi Rumah Kopi Billy ini dan pengamatan penulis RKB ramai di kunjungi baik pada waktu pagi, siang dan sore hingga malam hari. Kenyataan itulah yang mendorong penulis untuk meneliti "Kepuasan Konsumen Terhadap Produk Kopi di Rumah Kopi Billy Cabang Megamas Manado"

\section{Rumusan Masalah}

Berdasar uraian latar belakang tersebut maka perumusan masalah dalam penelitian ini adalah: Bagaimana tingkat kepuasan konsumen di Rumah Kopi Billy Cabang Megamas Manado ditinjau dari segi produk kopi dan pelayanan dari karyawan yang bekerja di Rumah Kopi Billy tempat produk kopi dibeli.

\section{Tujuan Penelitian}

Tujuan penelitian ini adalah: Mengetahui tingkat kepuasan konsumen di Rumah Kopi Billy Cabang Megamas Manado ditinjau dari segi produk kopi dan pelayanan dari karyawan yang bekerja di Rumah Kopi Billy tempat produk kopi dibeli.

\section{Manfaat Penelitian}

1. Sebagai masukan dan pertimbangan bagi pemilik Rumah Kopi Billy Cabang Megamas Manado dalam mengembangkan strategi menghadapi persaingan, sehingga dapat dijadikan pertimbangan dalam pengembangan strategi di masa yang akan datang.

2. Sebagai bahan masukan dan referensi bagi pihak-pihak yang berkepentingan terhadap masalah kepuasan konsumen. 
3. Sebagai bahan masukan atau tambahan pengetahuan bagi rekan-rekan mahasiswa serta masyarakat umum.

\section{METODE PENELITIAN}

\section{Tempat dan Waktu Penelitian}

Penelitian ini dilakukan di Rumah Kopi Billy Cabang Megamas, Jl. Dr. Sam Ratulangi, Manado. Waktu penelitian dilakukan pada bulan Juli 2016 - Agustus 2016.

\section{Populasi}

\section{Populasi dan Sampel}

Populasi dalam penelitian ini adalah para konsumen yang meminum kopi di Rumah Kopi Billy Cabang Megamas Manado.

\section{Sampel}

Metode yang digunakan dalam pengambilan sampel ini adalah accindental sampling, dimana peneliti mengambil responden sebagai sampel berdasarkan kebetulan, yaitu siapa saja yang secara kebetulan bertemu dengan peneliti di Rumah Kopi Billy Cabang Megamas Manado dapat digunakan sebagai sampel bila orang yang kebetulan ditemui cocok sebagai sumber data dengan kriteria utamanya adalah orang tersebut merupakan konsumen yang sedang meminum kopi. Peneliti akan memilih siapa saja yang ditemui di lokasi penelitian dan bersedia untuk dijadikan responden. Responden ini adalah konsumen yang bersedia untuk diwawancara dengan kuesioner.

Karena populasi dalam penelitian ini tidak diketahui dengan pasti jumlahnya, maka dari populasi ini diambil sampel untuk mewakili populasi tersebut.

Teknik pengambilan sampel ditentukan dari rumus berikut: Ferdinand (2006)

$$
\begin{aligned}
\mathrm{N} & =\{25 \mathrm{x} \text { jumlah variabel penelitian }\} \\
& =25 \times 2 \\
& =50 \text { sampel }
\end{aligned}
$$

Dari perhitungan di atas, maka diperoleh jumlah sampel yang akan diteliti yaitu sebesar 50 responden.

\section{Metode Pengumpulan Data}

Data yang digunakan dalam penelitian ini adalah data primer. Data primer diperoleh dengan menggunakan teknik wawancara langsung kepada responden, dalam hal ini konsumen produk kopi di Rumah Kopi Billy Cabang Megamas Manado, dengan menggunakan daftar pertanyaan (kuesioner) sebagai alat bantu dalam pengumpulan data.

\section{Konsep Pengukuran Variabel}

\section{Karakteristik responden :}

a. Jenis kelamin (laki-laki/perempuan)

b. Umur: usia jumlah tahun sejak responden dilahirkan (tahun).

c. Tingkat Pendidikan Terakhir: lamanya responden duduk di bangku sekolah formal (SLTP/SMU/ Diploma/Sarjana)

d. Pekerjaan : profesi dari responden pada saat wawancara dilaksanakan

\section{Tingkat kepuasan konsumen oleh Rumah Kopi Billy Cabang Megamas Manado dari segi produk, yaitu : \\ a. Variasi produk minuman kopi \\ b. Aroma kopi \\ c. Ukuran pada setiap porsi \\ d. Higienitas produk kopi yang di hidangkan \\ e. Cita rasa dari produk kopi}

\section{Tingkat kepuasan konsumen oleh Rumah} Kopi Billy Cabang Megamas Manado dari segi pelayanan. Secara rinci disebutkan sebagai berikut :

a. Kecepatan karyawan dalam penyajian kopi yang di pesan

b. Kesigapan karyawan

c. Pengetahuan karyawan terhadap produk kopi yang di jual

d. Penampilan fisik karyawan

e. Keramahan karyawan dalam melayani konsumen

\section{Analisis Data}

Penelitian ini menggunakan metode analisis data, yaitu metode analisis data kualitatif deskriptif. Metode analisis deskriptif adalah metode penelitian yang melibatkan analisis data berupa deskriptif dan data tersebut tidak secara langsung dapat dikuantifikasi. Analisis deskriptif merupakan metode pencarian fakta dengan interpretasi yang tepat mengenai masalah-masalah yang ada dalam masyarakat, 
tata cara yang berlaku, serta situasi-situasi tertentu termasuk tentang hubungan, kegiatan, sikap, pandangan, serta proses yang sedang berlangsung dan pengaruh dari suatu fenomena.

Dengan menggunakan analisis deskriptif ini maka akan diperoleh gambaran mengenai kepuasan konsumen terhadap produk kopi.

a. Untuk mengetahui bagaimana tingkat kepuasan konsumen di Rumah Kopi Billy Cabang Megamas Manado ditinjau dari segi produk kopi dan pelayanan.

Analisis data dalam penelitian ini adalah analisis data deskriptif dengan menggunakan daftar tabel dan angka. Untuk mengukur sikap akan disusun 10 pertanyaan dengan total responden 50. Setiap jawaban dihubungkan dengan bentuk pernyataan atau dukungan sikap yang diungkapkan dengan kata-kata berikut:

$\begin{array}{lll}\text { Sangat puas } & = & \text { Skor 5 } \\ \text { Puas } & = & \text { Skor } 4 \\ \text { Cukup puas } & = & \text { Skor 3 } \\ \text { Tidak puas } & = & \text { Skor 2 } \\ \text { Sangat tidak puas } & = & \text { Skor 1 }\end{array}$

Dengan cara perhitungan skor masingmasing pertanyaan :

Jumlah Skor Tiap Kriterium $=$ Capaian Skor $\times$ Jumlah Responden.

Untuk :

$\mathrm{S} 5=5 \times 50=250$

$\mathrm{S} 4=4 \times 50=200$

$\mathrm{S} 3=3 \times 50=150$

$\mathrm{S} 2=2 \times 50=100$

$\mathrm{S} 1=1 \times 50=50$

Jumlah skor ideal untuk keseluruhan pertanyaan $=250$

Jumlah skor terendah $=50$

Dengan interpretasi nilai :

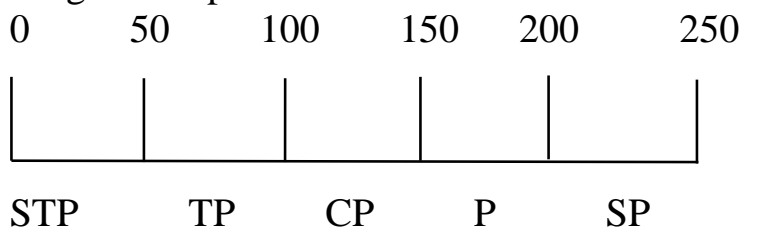

Cara perhitungan skor keseluruhan untuk mengetahui tingkat kepuasan konsumen terhadap produk kopi yang dijual di Rumah Kopi Billy Cabang Megamas Manado ditinjau dari segi produk kopi dan pelayanan:

Jumlah Skor Seluruh Kriterium = Capaian
Jumlah Skor $\times$ Jumlah Responden $\times$ Jumlah Keseluruhan instrument pertanyaan (Indikator) Untuk :
$\mathrm{S} 5=5 \times 50 \times 10=2500$
$\mathrm{S} 4=4 \times 50 \times 10=2000$
$\mathrm{S} 3=3 \times 50 \times 10=1500$
$\mathrm{S} 2=2 \times 50 \times 10=1000$
$\mathrm{S} 1=1 \times 50 \times 10=500$

Jumlah skor ideal untuk keseluruhan pertanyaan $=2500$ (tertinggi)

Jumlah skor terendah $=500$ (rendah)

Dengan indeks tingkat kepuasan konsumen :

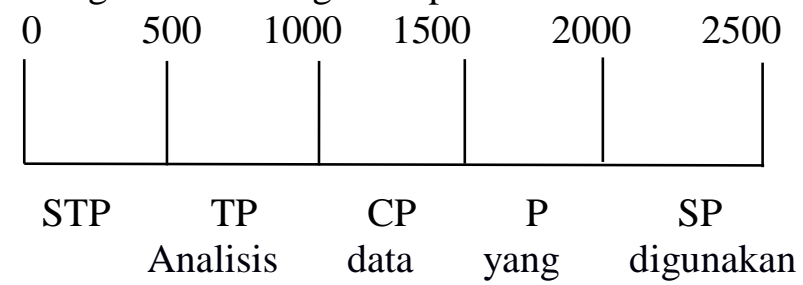
merupakan analisis deskriptif yang dianalisis dengan menggunakan skala pengukuran sikap Likert Scale dimana menurut Riduwan (2008) dalam buku Rumus dan Data dalam Analisis Statistika, adalah sebagai berikut :

Tingkat Kepuasan Konsumen = $\frac{\text { JumlahSkorHasilPengumpulanData }}{\text { JumlahSkorIdeal (Tertingii) }} \times 100 \%$

Dengan indeks tingkat kepuasan konsumen

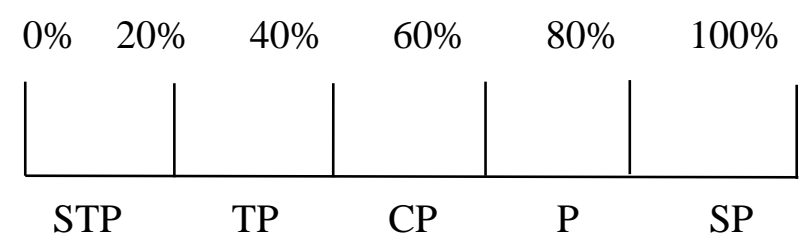

Keterangan : Kriteria interpretasi skor Angka $0 \%-20 \%=$ Sangat tidak puas Angka 21\% - 40\% = Tidak puas Angka 41\% - 60\% = Cukup puas Angka $61 \%-80 \%=$ Puas Angka $81 \%-100 \%=$ Sangat puas

\section{Uji Validitas dan Reliabilitas}

\section{Uji Validitas Kuesioner}

Uji coba validitas dari indikator dianalisis menggunakan $\mathrm{df}$ (degree of freedom) dengan rumus $\mathrm{df}=\mathrm{n}-\mathrm{k}$, dimana $\mathrm{n}=$ jumlah sampel, $\mathrm{k}=$ jumlah variabel independen. Jadi, df yang digunakan adalah $50-2=48$ dengan alpha sebesar $5 \%$ maka menghasilkan nilai $r$ - 
tabel sebesar 0,284. Uji validitas ini dilakukan kepada 48 responden diluar sampel dengan wawancara pada konsumen Rumah Kopi Billy Cabang Megamas Manado.

Tabel 1 menunjukkan bahwa seluruh butir pertanyaan valid, yang dapat dilihat dari $\mathrm{r}$ hitung Corrected Item-Total Correclation yang pada keseluruhan butir lebih besar dari r-tabel $(0,284)$ sehingga diperoleh 10 pertanyaan valid yang digunakan untuk melakukan penelitian

\section{Uji Reliabilitas Kuesioner}

Uji Reliabilitas merupakan alat untuk mengukur suatu kuesioner yang merupakan indikator dari variabel atau konstruk. Suatu kuesioner dikatakan reliable atau handal jika jawaban seseorang terhadap pertanyaan konsisten atau stabil dari waktu ke waktu.

Uji reabilitas dilakukan dengan menggunakan rumus alpha. Kuesioner dinyatakan reliabel apabila alpha > r-tabel $(0,284)$.

Berdasarkan pengujian pada Tabel 2 uji reliabilitas, diketahui bahwa semua variabel mempunyai nilai Cronbach's Alpha lebih besar dari 0,284. Maka dapat disimpulkan bahwa keseluruhan variabel dalam penelitian ini reliabel

Tabel 1. Hasil Pengujian Validitas

\begin{tabular}{lcccc}
\hline \multirow{2}{*}{ Variabel } & $\begin{array}{c}\text { Butir } \\
\text { Pertanyaan }\end{array}$ & r-hitung & r-tabel & Ket \\
\hline \multirow{3}{*}{ Produk Kopi } & X1_1 & 0,735 & 0,284 & Valid \\
& X1_2 & 0,768 & 0,284 & Valid \\
& X1_3 & 0,637 & 0,284 & Valid \\
X1_4 & 0,806 & 0,284 & Valid \\
& X1_5 & 0,669 & 0,284 & Valid \\
& & & & \\
& X2_6 & 0,666 & 0,284 & Valid \\
& X2_7 & 0,670 & 0,284 & Valid \\
& X2_8 & 0,736 & 0,284 & Valid \\
& X2_9 & 0,792 & 0,284 & Valid \\
P2_10 & 0,658 & 0,284 & Valid
\end{tabular}

Sumber: Diolah dari data primer, 2016

Tabel 2. Hasil Pengujian Reliabilitas

\begin{tabular}{cccl}
\hline Variabel & $\begin{array}{c}\text { Cronbach's } \\
\text { Alpha }\end{array}$ & $\begin{array}{c}\text { N of } \\
\text { Items }\end{array}$ & Keterangan \\
\hline Produk & 0,782 & 5 & Reliabel \\
Pelayanan & 0,745 & 5 & Reliabel \\
\hline
\end{tabular}

Sumber: Diolah dari data primer, 2016 


\section{HASIL ANALISIS DAN PEMBAHASAN}

\section{Profil Perusahaan}

\section{Deskripsi Perusahaan}

Rumah Kopi Billy Cabang Megamas Manado merupakan salah satu kafé kopi yang berdiri di Kawasan Megamas Manado. Rumah Kopi Billy Cabang Megamas berdiri pada Februari 2011, kafe ini didirikan oleh keluarga besar Palit - Rondonuwu. Rumah Kopi Billy Cabang Megamas diolah secara kekeluargaan untuk saling mendukung satu dengan yang lain, bukan berstruktur perusahaan. RKB telah tersebar di beberapa tempat, sudah ada di Jalan 17 Agustus, Area Marina Plaza, Airmadidi dan RKB yang original berada di Jalan Sam Ratulangi, dekat Rumah Sakit Pancaran Kasih. Semuanya dikelola oleh keluarga besar Palit - Rondonuwu. Rumah Kopi Billy juga sudah melebarkan usahanya keluar kota Manado, tepatnya di Kelapa Gading Jakarta dan di Ja lan Grand Galaxy Boulevard, Bekasi Selatan.

\section{Karakteristik Responden Berdasarkan Jenis Kelamin}

Berikut ini adalah deskripsi responden dalam penelitian ini berdasarkan jenis kelamin dan umur:

Tabel 3 menunjukkan banyaknya responden yang datang di Rumah Kopi Billy Cabang Megamas Manado dilihat dari jenis kelamin. Responden terbanyak adalah responden dengan jenis kelamin laki-laki sebesar $62 \%$ dan sisanya berjenis kelamin perempuan sebesar $38 \%$. Proporsi konsumen yang berkunjung di Rumah Kopi Billy Cabang Megamas Manado berjenis kelamin laki-laki lebih banyak daripada berjenis kelamin perempuan.

\section{Karakteristik Responden Berdasarkan Usia}

Berdasarkan pada Tabel 4 di bawah, usia responden paling banyak adalah responden dengan usia kurang dari 25 tahun yaitu sebesar $62 \%$. Untuk responden yang berusia antara $25-$ 40 tahun terdapat sebanyak 38\%. Hasil deskripsi ini mengindikasikan bahwa sebagian besar konsumen Rumah Kopi Billy Cabang Megamas Manado adalah anak muda dan orang dewasa yang belum lanjut usia.

\section{Karakteristik Responden Berdasarkan Tingkat Pendidikan Terakhir \\ Karekteristik berdasarkan jenis} pendidikan terakhir ini berguna untuk pendukung analisis di mana konsumen terbanyak yang mempercayakan tempat makan di Rumah Kopi Billy Cabang Megamas Manado berdasarkan usia adalah anak muda. Berikut ini adalah deskripsi responden dalam penelitian ini berdasarkan tingkat pendidikan terakhir yang ada di Rumah Kopi Billy Cabang Megamas Manado.

\section{Deskripsi Responden}

Responden yang digunakan dalam penelitian ini merupakan responden yang ditemui di Rumah Kopi Billy Cabang Megamas Manado. Hasil dari penyebaran kuesioner sebanyak 50 responden didapatkan karakteristik responden berdasarkan jenis kelamin, umur, tingkat pendidikan terakhir, dan pekerjaan. Berikut dipaparkan hasil dari masing-masing karakteristik responden yang ditemui di Rumah Kopi Billy Cabang Megamas Manado.

Tabel 3. Karakteristik Responden Berdasarkan Jenis Kelamin

\begin{tabular}{ccc}
\hline Jenis Kelamin & Frekuensi & Persentase (\%) \\
\hline Laki-laki & 31 & 62 \\
Perempuan & 19 & 38 \\
\hline Total & 50 & 100 \\
\hline
\end{tabular}

Sumber: Diolah dari data primer, 2016

Tabel 4. Karakteristik Responden Berdasarkan Usia

\begin{tabular}{cccc}
\hline Usia & Frekuensi & \multicolumn{2}{c}{ Persentase (\%) } \\
\hline$<25$ tahun & 36 & 38 & \\
$25-40$ tahun & 14 & 38 & 100 \\
\hline Total & 50 &
\end{tabular}

Sumber: Diolah dari data primer, 2016 
Berdasarkan hasil yang disajikan pada Tabel 5, banyaknya responden berdasarkan tingkat pendidikan terakhir terbanyak adalah tingkat pendidikan SMU sebesar $66 \%$. Konsumen yang memiliki tingkat pendidikan Sarjana sebanyak 20\%, sedangkan untuk tingkat pendidikan Diploma adalah sebesar $8 \%$ dan yang paling sedikit konsumen adalah yang berpendidikan SLTP sebesar $6 \%$. Berdasarkan hasil ini maka dapat diketahui bahwa konsumen terbanyak di Rumah Kopi Billy Cabang Megamas Manado adalah lulusan SMA atau bisa dikatakan kalangan mahasiswa.

\section{Karakteristik Responden Berdasarkan Pekerjaan}

Karakteristik responden selanjutnya adalah perdasarkan jenis pekerjaan. Data ini diperlukan untuk mengetahui berasal dari kalangan pekerjaan apa saja konsumen yang datang di Rumah Kopi Billy Cabang Megamas Manado. Berikut ini adalah deskripsi responden dalam penelitian ini berdasarkan pekerjaan

Berdasarkan hasil yang disajikan pada Tabel 6, dapat diketahui bahwa jumlah responden terbanyak bagi yang belum bekerja merupakan mahasiswa, yaitu 25 orang atau $50 \%$, diikuti oleh pelajar 3 orang atau $6 \%$, sedangkan bagi konsumen yang sudah bekerja merupakan wiraswasta sebanyak 18 orang atau $36 \%$ dan PNS 4 orang atau $8 \%$.

\section{Tingkat Kepuasan Konsumen Terhadap Produk Kopi di Rumah Kopi Billy Cabang Megamas Manado dari Segi Produk.}

\section{Kepuasan Konsumen terhadap Variasi Produk Minuman Kopi} Persepsi konsumen terhadap pernyataan/pertanyaan yang menyebutkan variasi produk minuman kopi, dapat dilihat pada Tabel 7. Hasil penelitian ini menunjukan total skor yang diperoleh dari total 50 responden pada indikator variasi produk minuman kopi adalah sebesar 200 (puas) dengan rata-rata angka indeks tingkat kepuasan konsumen terletak pada persentase : 200/250 $\times$ $100 \%=80 \%$ sehingga interpretasi nilainya tergolong puas. Artinya, konsumen produk kopi di Rumah Kopi Billy Cabang Megamas
Manado telah merasa puas dengan variasi produk minuman kopi yang ditawarkan.

\section{Kepuasan Konsumen terhadap Aroma Kopi \\ Persepsi konsumen terhadap} pernyataan/pertanyaan indikator aroma kopi terdapat pada Tabel 8. Hasil penelitian ini menunjukan total skor yang diperoleh dari total 50 responden pada indikator aroma kopi adalah sebesar 201 (sangat puas) dengan ratarata angka indeks tingkat kepuasan konsumen terletak pada persentase : $201 / 250 \times 100 \%=$ $80,4 \%$, sehingga interpretasi nilainya tergolong puas. Artinya, aroma dari suatu cangkir kopi yang disajikan sudah tepat dengan apa yang di harapkan oleh seorang konsumen mengenai aroma dari secangkir kopi.

\section{Kepuasan Konsumen terhadap Ukuran pada setiap Porsi}

Persepsi konsumen terhadap pernyataan/pertanyaan yang menyebutkan ukuran pada setiap porsi, dapat dilihat pada Tabel 9. Hasil penelitian ini menunjukan total skor yang diperoleh dari total 50 responden pada indikator ukuran pada porsi produk kopi adalah sebesar 185 (puas) dengan rata-rata angka indeks tingkat kepuasan konsumen terletak pada persentase : $185 / 250 \times 100 \%=$ $74 \%$, sehingga interpretasi nilainya tergolong puas. Hal ini menunjukan bahwa takaran ukur setiap porsi produk kopi yang dijual telah tepat dan mampu memuaskan konsumen.

\section{Kepuasan Konsumen terhadap Higienitas Produk Kopi \\ Persepsi konsumen terhadap} pernyataan/pertanyaan yang menyebutkan higienitas produk kopi, dapat dilihat pada Tabel 10. Hasil penelitian ini menunjukan total skor yang diperoleh dari total 50 responden pada indikator higienitas produk kopi adalah sebesar 191 (puas) dengan rata-rata angka indeks tingkat kepuasan konsumen terletak pada persentase : $191 / 250 \times 100 \%=76,4 \%$, sehingga interpretasi nilainya tergolong puas. Hal ini menunjukan bahwa kebersihan dari secangkir kopi yang disajikan oleh Rumah Kopi Billy Cabang Megamas Manado dapat memuaskan konsumen. 
Tabel 5. Karakteristik Responden Berdasarkan Tingkat Pendidikan Terakhir

\begin{tabular}{ccc}
\hline Tingkat Pendidikan Terakhir & Frekuensi & $\begin{array}{c}\text { Persentase } \\
(\%)\end{array}$ \\
& & 6 \\
SLTP & 3 & 66 \\
SMU & 33 & 8 \\
Diploma & 4 & 20 \\
Sarjana & 10 & 100 \\
\hline Total & 50 &
\end{tabular}

Sumber: Diolah dari data primer, 2016

Tabel 6. Karakteristik Responden Berdasarkan Pekerjaan

\begin{tabular}{|c|c|c|c|c|}
\hline Status & Pekerjaan & \multicolumn{2}{|c|}{ Frekuensi } & Persentase $(\%)$ \\
\hline Belum Bekerja & Pelajar & \multicolumn{2}{|c|}{3} & 6 \\
\hline Sudah Bekerja & Mahasiswa & \multicolumn{2}{|c|}{25} & 50 \\
\hline & PNS & \multicolumn{2}{|c|}{4} & 8 \\
\hline & Wiraswasta & \multicolumn{2}{|c|}{18} & 36 \\
\hline Total & & \multicolumn{2}{|c|}{50} & 100 \\
\hline \multicolumn{5}{|c|}{ Sumber: Diolah dari data primer, 2016} \\
\hline \multicolumn{5}{|c|}{ Tabel 7. Variasi Produk Minuman Kopi } \\
\hline Alternatif Jawaban & Alternatif & Jumlah & Persentase & Total Skor \\
\hline & Skor & $\begin{array}{l}\text { Responden } \\
\text { (Orang) }\end{array}$ & $\begin{array}{c}\text { Responden } \\
(\%)\end{array}$ & \\
\hline Sangat Puas & 5 & 12 & 24 & 60 \\
\hline Puas & 4 & 27 & 54 & 108 \\
\hline Cukup Puas & 3 & 10 & 20 & 30 \\
\hline Tidak Puas & 2 & 1 & 2 & 2 \\
\hline Sangat Tidak Puas & 1 & - & - & - \\
\hline Total & & 50 & 100 & 200 \\
\hline
\end{tabular}

Sumber: Diolah dari data primer, 2016

Tabel 8. Aroma Kopi

Alternatif Jawaban Alternatif Jumlah Responden

Skor (Orang) Responden

$(\%)$

\begin{tabular}{ccccc}
\hline Sangat Puas & 5 & 13 & 26 & 65 \\
Puas & 4 & 25 & 50 & 100 \\
Cukup Puas & 3 & 12 & 24 & 36 \\
Tidak Puas & 2 & - & - & - \\
Sangat Tidak Puas & 1 & - & - & - \\
\hline Total & & 50 & 100 & 201 \\
\hline
\end{tabular}

Sumber: Diolah dari data primer, 2016 
Tabel 9. Ukuran pada setiap porsi

\begin{tabular}{ccccc}
\hline Alternatif Jawaban & $\begin{array}{c}\text { Alternatif } \\
\text { Skor }\end{array}$ & $\begin{array}{c}\text { Jumlah Responden } \\
\text { (Orang) }\end{array}$ & $\begin{array}{c}\text { Persentase } \\
\text { Responden } \\
(\%)\end{array}$ & Total Skor \\
\hline Sangat Puas & 5 & 8 & 16 & 40 \\
Puas & 4 & 24 & 48 & 96 \\
Cukup Puas & 3 & 14 & 28 & 42 \\
Tidak Puas & 2 & 3 & 6 & 6 \\
Sangat Tidak Puas & 1 & 1 & 2 & 1 \\
\hline Total & & 50 & 100 & 185 \\
\hline
\end{tabular}

Sumber: Diolah dari data primer, 2016

Tabel 10. Higienitas Produk Kopi

\begin{tabular}{ccccc}
\hline Alternatif Jawaban & $\begin{array}{c}\text { Alternatif } \\
\text { Skor }\end{array}$ & $\begin{array}{c}\text { Jumlah Responden } \\
\text { (Orang) }\end{array}$ & $\begin{array}{c}\text { Persentase } \\
\text { Responden } \\
(\%)\end{array}$ & Total Skor \\
\hline Sangat Puas & 5 & 9 & 18 & 45 \\
Puas & 4 & 23 & 46 & 92 \\
Cukup Puas & 3 & 18 & - & 54 \\
Tidak Puas & 2 & - & - & - \\
Sangat Tidak Puas & 1 & - & 100 & 191 \\
\hline Total & & 50 &
\end{tabular}

Sumber: Diolah dari data primer, 2016

\section{Kepuasan Konsumen terhadap Cita Rasa dari Produk Kopi}

Persepsi konsumen terhadap pernyataan/pertanyaan yang menyebutkan cita rasa dari produk kopi, dapat dilihat pada Tabel 11. Hasil penelitian ini menunjukan total skor yang diperoleh dari total 50 responden pada indikator cita rasa dari produk kopi adalah sebesar 212 (sangat puas) dengan rata-rata angka indeks tingkat kepuasan konsumen terletak pada persentase : $212 / 250 \times 100 \%=84,8 \%$, sehingga interpretasi nilainya tergolong sangat puas. Hal ini menunjukan bahwa cita rasa produk kopi yang di jual telah tepat dan konsumen merasa sangat terpuaskan dengan cita rasa produk kopi di Rumah Kopi Billy Cabang Megamas Manado.

\section{Rekapitulasi Pengukuran Kepuasan Kepuasan Konsumen Terhadap Produk Kopi di Rumah Kopi Billy Cabang Megamas Manado dari Segi Produk.}

Tabel 12 menunjukan rekapitulasi total skor, indeks kepuasan dan interpretasi dari Persepsi Konsumen terhadap Produk Kopi dari Segi Produk. Tabel 12 menunjukkan bahwa terdapat 5 indikator persepsi kepuasan konsumen terhadap produk kopi dari segi produk, dimana pertanyaan 5 mendapat indeks kepuasan $84.8 \%$ (sangat puas), pertanyaan 2 mendapat indeks kepuasan $80.4 \%$ (puas), pertanyaan 1 mendapat indeks kepuasan $80 \%$ (puas), pertanyaan 4 mendapat indeks kepuasan $76.4 \%$ (puas), dan pernyataan 3 mendapat indeks kepuasan $74 \%$ (puas).

\section{Tingkat Kepuasan Konsumen di Rumah Kopi Billy Cabang Megamas Manado dari Segi Pelayanan.}

\section{Kepuasan Konsumen terhadap Kecepatan Karyawan dalam Penyajian Kopi}

Persepsi konsumen terhadap pernyataan/pertanyaan yang menyebutkan kecepatan karyawan dalam penyajian kopi, dapat dilihat pada Tabel 13. Hasil penelitian ini menunjukkan bahwa total skor yang diperoleh dari total 50 responden pada indikator kecepatan karyawan dalam penyajian produk kopi adalah sebesar 210 (sangat puas) dengan rata-rata angka indeks tingkat kepuasan konsumen terletak pada persentase : $210 / 250 \times 100 \%=84 \%$, sehingga interpretasi nilainya tergolong sangat puas. Artinya, kecepatan karyawan Rumah Kopi Billy Cabang Megamas Manado dalam menyajikan suatu cangkir kopi yang dipesan pelanggan sudah tepat, pelanggan tidak menunggu terlalu lama untuk mendapatkan secangkir kopi yang dipesannya. 
Tabel 11. Cita Rasa dari Produk Kopi

\begin{tabular}{ccccc}
\hline Alternatif Jawaban & $\begin{array}{c}\text { Alternatif } \\
\text { Skor }\end{array}$ & $\begin{array}{c}\text { Jumlah } \\
\text { Responden } \\
\text { (Orang) }\end{array}$ & $\begin{array}{c}\text { Persentase } \\
\text { Responden } \\
(\%)\end{array}$ & $\begin{array}{c}\text { Total } \\
\text { Skor }\end{array}$ \\
\hline Sangat Puas & 5 & 21 & 42 & 105 \\
Puas & 4 & 20 & 40 & 80 \\
Cukup Puas & 3 & 9 & 18 & 27 \\
Tidak Puas & 2 & - & - & - \\
Sangat Tidak Puas & 1 & - & - & - \\
\hline Total & & 50 & 100 & 212 \\
\hline
\end{tabular}

Sumber: Diolah dari data primer, 2016

Tabel 12. Rekapitulasi Jumlah Skor Pengambilan Data, Indeks Kepuasan, dan Interpretasi pada Indikator Persepsi Kepuasan Konsumen terhadap Produk Kopi dari Segi Produk

\begin{tabular}{|c|c|c|c|c|}
\hline NO & PERNYATAAN & TOTAL SKOR & $\begin{array}{c}\text { INDEKS } \\
\text { KEPUASAN } \\
(\%)\end{array}$ & INTERPRETASI \\
\hline 1 & Variasi Produk Minuman Kopi & 200 & 80 & Puas \\
\hline 2 & Aroma Kopi & 201 & 80.4 & Puas \\
\hline 3 & Porsi Produk Kopi & 185 & 74 & Puas \\
\hline 4 & Higienitas Produk Kopi & 191 & 76,4 & Puas \\
\hline 5 & Cita Rasa dari Produk Kopi & 212 & 84,8 & Sangat Puas \\
\hline
\end{tabular}

Sumber: Diolah dari data primer, 2016

Tabel 13. Kecepatan Karyawan dalam Penyajian Kopi

\begin{tabular}{ccccc}
\hline Alternatif Jawaban & $\begin{array}{c}\text { Alternatif } \\
\text { Skor }\end{array}$ & $\begin{array}{c}\text { Jumlah } \\
\text { Responden } \\
\text { (Orang) }\end{array}$ & $\begin{array}{c}\text { Persentase } \\
\text { Responden } \\
(\%)\end{array}$ & Total Skor \\
\hline Sangat Puas & 5 & 18 & 36 & 90 \\
Puas & 4 & 26 & 52 & 104 \\
Cukup Puas & 3 & 4 & 8 & 12 \\
Tidak Puas & 2 & 2 & 4 & 4 \\
Sangat Tidak Puas & 1 & - & - & - \\
\hline Total & & 50 & 100 & 210
\end{tabular}

Sumber : Diolah dari data primer, 2016 
Kepuasan Konsumen terhadap Kesigapan Karyawan dalam Memberikan Pelayanan

Persepsi konsumen terhadap pernyataan/pertanyaan yang menyebutkan bahwa kesigapan karyawan dalam memberikan pelayanan, dapat dilihat pada Tabel 14. Hasil penelitian ini menunjukkan bahwa total skor yang diperoleh dari total 50 responden pada indikator kesigapan karyawan dalam memberikan pelayanan adalah sebesar 253 (sangat puas) dengan rata-rata angka indeks tingkat kepuasan konsumen terletak pada persentase : $253 / 250 \times$ $100 \%=101,2 \%$, sehingga interpretasi nilainya tergolong sangat puas. Artinya, karyawan Rumah Kopi Billy Cabang Megamas Manado telah siap dan cepat dalam melayani setiap permintaan dari pelanggan, tentunya dengan ini pelanggan merasa sangat terpuaskan.

\section{Kepuasan Konsumen terhadap Pengetahuan karyawan terhadap Produk Kopi yang di Jual}

Persepsi konsumen terhadap penyataan no 8 yang menyebutkan pengetahuan karyawan terhadap produk kopi yang di jual, dapat dilihat pada Tabel 15. Hasil penelitian ini menunjukkan bahwa total skor yang diperoleh dari total 50 responden pada indikator pengetahuan karyawan terhadap produk kopi yang di jual adalah sebesar 197 (puas) dengan rata-rata angka indeks tingkat kepuasan konsumen terletak pada persentase : $197 / 250 \times 100 \%=78,8 \%$, sehingga interpretasi nilainya tergolong puas. Artinya, karyawan Rumah Kopi Billy Cabang Megamas Manado telah mengetahui apa saja mengenai produk kopi yang mereka jual, sehingga apabila seorang pelanggan bertanya tentang produk kopi, karyawan mampu menjelaskan dengan baik mengenai produk kopi yang di jual dan pelanggan tidak bingung dengan apa yang mau dipesannya.

\section{Kepuasan Konsumen terhadap Penampilan Fisik Karyawan}

Persepsi konsumen

terhadap pernyataan/pertanyaan yang menyebutkan penampilan fisik karyawan, dapat dilihat pada Tabel 16. Hasil penelitian ini menunjukan bahwa total skor yang diperoleh dari total 50 responden pada indikator penampilan fisik karyawan adalah sebesar 213 (sangat puas) dengan rata-rata angka indeks tingkat kepuasan konsumen terletak pada persentase : $213 / 250 \times 100 \%=85,2 \%$, sehingga interpretasi nilainya tergolong sangat puas. Artinya, pelanggan merasa puas dengan penampilan karyawan Rumah Kopi Billy Cabang Megamas Manado dalam berpakaian, kerapihan dan kebersihan karyawan itu sendiri.

\section{Kepuasan Konsumen terhadap Keramahan Karyawan dalam Memberikan Pelayanan}

Persepsi konsumen terhadap penyataan/pertanyaan yang menyebutkan keramahan karyawan dalam memberikan pelayanan, dapat dilihat pada Tabel 17. Hasil penelitian ini menunjukkan bahwa total skor yang diperoleh dari total 50 responden pada indikator keramahan karyawan dalam memberikan pelayanan adalah sebesar 228 (sangat puas) dengan rata-rata angka indeks tingkat kepuasan konsumen terletak pada persentase : $228 / 250 \times 100 \%=91,2 \%$, sehingga interpretasi nilainya tergolong sangat puas. Hal ini menunjukan bahwa keramahan karyawan dalam memberikan pelayanan sudah tepat dan pelanggan merasa sangat terpuaskan.

\section{Rekapitulasi Pengukuran Kepuasan Konsumen di Rumah Kopi Billy Cabang Megamas Manado dari Segi Pelayanan.}

Rekapitulasi pengukuran tingkat kepuasan konsumen produk kopi di Rumah Kopi Billy Cabang Megamas Manado dari segi pelayanan. Tabel 18 menunjukkan bahwa terdapat 5 indikator persepsi kepuasan konsumen terhadap produk kopi dari segi pelayanan dimana pernyataan 2 adalah indeks kepuasan tertinggi, yaitu $101,2 \%$ (sangat puas), sedangkan pernyataan 5 mendapat indeks $91.2 \%$ (sangat puas), pernyataan 4 mendapat indeks kepuasan $85.2 \%$ (sangat puas), pernyataan 1 mendapat indeks kepuasan $84 \%$ (sangat puas), dan pernyataan 3 mendapat indeks kepuasan $78.8 \%$ (puas). 
Tabel 14. Kesigapan Karyawan dalam Memberikan Pelayanan

\begin{tabular}{ccccc}
\hline Alternatif Jawaban & $\begin{array}{c}\text { Alternatif } \\
\text { Skor }\end{array}$ & $\begin{array}{c}\text { Jumlah } \\
\text { Responden } \\
\text { (Orang) }\end{array}$ & $\begin{array}{c}\text { Persentase } \\
\text { Responden } \\
(\%)\end{array}$ & Total Skor \\
\hline Sangat Puas & 5 & 23 & 46 & 115 \\
Puas & 4 & 22 & 44 & 88 \\
Cukup Puas & 3 & 5 & 10 & 50 \\
Tidak Puas & 2 & - & - & - \\
Sangat Tidak Puas & 1 & - & - & 253 \\
\hline Total & & 50 & 100 & \\
\hline
\end{tabular}

Tabel 15. Pengetahuan Karyawan terhadap Produk Kopi yang di Jual

\begin{tabular}{ccccc}
\hline Alternatif Jawaban & $\begin{array}{c}\text { Alternatif } \\
\text { Skor }\end{array}$ & $\begin{array}{c}\text { Jumlah } \\
\text { Responden } \\
\text { (Orang) }\end{array}$ & $\begin{array}{c}\text { Persentase } \\
\text { Responden } \\
(\%)\end{array}$ & Total Skor \\
\hline Sangat Puas & 5 & 16 & 32 & 80 \\
Puas & 4 & 20 & 40 & 80 \\
Cukup Puas & 3 & 11 & 22 & 33 \\
Tidak Puas & 2 & 1 & 2 & 2 \\
Sangat Tidak Puas & 1 & 2 & 100 & 197 \\
\hline Total & & 50 & &
\end{tabular}

Sumber : Diolah dari data primer, 2016

Tabel 16. Penampilan Fisik Karyawan

\begin{tabular}{ccccc}
\hline Alternatif Jawaban & $\begin{array}{c}\text { Alternatif } \\
\text { Skor }\end{array}$ & $\begin{array}{c}\text { Jumlah } \\
\text { Responden } \\
\text { (Orang) }\end{array}$ & $\begin{array}{c}\text { Persentase } \\
\text { Responden } \\
(\%)\end{array}$ & Total Skor \\
\hline Sangat Puas & 5 & 21 & 42 & 105 \\
Puas & 4 & 21 & 42 & 84 \\
Cukup Puas & 3 & 8 & 16 & 24 \\
Tidak Puas & 2 & - & - & - \\
Sangat Tidak Puas & 1 & - & - & - \\
\hline Total & & 50 & 100 & 213 \\
\hline
\end{tabular}

Sumber : Diolah dari data primer, 2016

Tabel 17. Keramahan Karyawan dalam Memberikan Pelayanan

\begin{tabular}{ccccc}
\hline Alternatif Jawaban & $\begin{array}{c}\text { Alternatif } \\
\text { Skor }\end{array}$ & $\begin{array}{c}\text { Jumlah } \\
\text { Responden } \\
\text { (Orang) }\end{array}$ & $\begin{array}{c}\text { Persentase } \\
\text { Responden } \\
(\%)\end{array}$ & Total Skor \\
\hline Sangat Puas & 5 & 31 & 62 & 155 \\
Puas & 4 & 16 & 32 & 64 \\
Cukup Puas & 3 & 3 & 6 & 9 \\
Tidak Puas & 2 & - & - & - \\
Sangat Tidak Puas & 1 & - & - & 228 \\
\hline Total & & 50 & 100 &
\end{tabular}

Sumber : Diolah dari data primer, 2016 


\begin{tabular}{|c|c|c|c|c|}
\hline $\mathrm{NO}$ & PERNYATAAN & TOTAL SKOR & $\begin{array}{l}\text { INDEKS } \\
\text { KEPUASAN } \\
(\%)\end{array}$ & $\begin{array}{l}\text { INTERPRETAS } \\
\text { I }\end{array}$ \\
\hline 1 & $\begin{array}{l}\text { Kecepatan Karyawan dalam } \\
\text { Penyajian Kopi yang di Pesan }\end{array}$ & 210 & 84 & Sangat Puas \\
\hline 2 & $\begin{array}{l}\text { Kesigapan Karyawan dalam } \\
\text { Memberikan Pelayanan }\end{array}$ & 253 & 101,2 & Sangat Puas \\
\hline 3 & $\begin{array}{l}\text { Pengetahuan Karyawan } \\
\text { terhadap Produk Kopi yang di } \\
\text { Jual }\end{array}$ & 197 & 78.8 & Puas \\
\hline 4 & Penampilan Fisik Karyawan & 213 & 85.2 & Sangat Puas \\
\hline 5 & $\begin{array}{l}\text { Keramahan Karyawan dalam } \\
\text { Memberikan Pelayanan }\end{array}$ & 228 & 91.2 & Sangat Puas \\
\hline
\end{tabular}

Sumber : Diolah dari data primer, 2016

\section{Rekapitulasi Indeks Persepsi Kepuasan pada masing-masing Indikator dan Interpretasi Hasil}

Rekapitulasi pengukuran tingkat kepuasan konsumen di Rumah Kopi Billy Cabang Megamas dari segi produk kopi dan pelayanan dengan menggunakan 10 instrumen pertanyaan (indikator) dapat dilihat pada Tabel 19 berikut. Untuk mengetahui letak kepuasan konsumen terhadap produk kopi dari segi produk dan pelayanan, maka perlu dihitung jumlah keseluruhan skor pada setiap kriterium, dimana sesuai hasil penelitian ini skor mencapai 2.090. Pada penelitian ini, jumlah skor ideal (skor tertinggi), yaitu 2.500 (tinggi) dan jumlah skor terendah yaitu 500 (rendah).

Berdasarkan data yang dihimpun dari 10 instrumen pertanyaan yang diajukan kepada 50 responden, maka diperoleh total 2500 , dengan letak indeks ditentukan berdasarkan skala likert berikut :

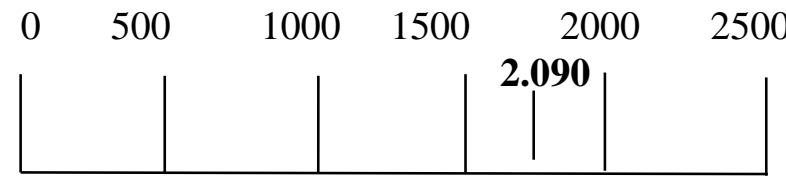

$\begin{array}{lllll}\text { STP } & \text { TP } & \text { CP } & \text { P } & \text { SP }\end{array}$
Berdasarkan skala diatas, dapat dilihat bahwa kepuasan konsumen dari segi produk dan pelayanan di Rumah Kopi Billy Cabang Megamas terletak pada daerah sangat puas. Secara persentase, angka indeks persepsi kepuasan konsumen dari segi produk dan pelayanan terletak pada:

Tingkat Kepuasan Konsumen $=$ $\frac{\text { JumlahSkorHasilPengumpulanData }}{\text { JumlahSkorIdeal (Tertinggi) }} \times 100 \%$

Tingkat Kepuasan Konsumen $=\frac{2.090}{2.500} \times$ $100 \%$

$$
=83.6 \%
$$

Dengan interpretasi nilai :

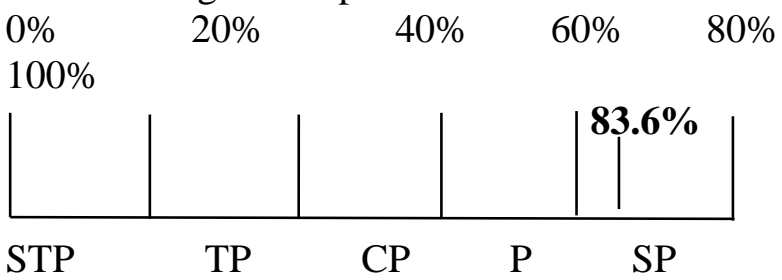

Berdasarkan hasil analisis menggunakan skala likert, maka dapat diketahui bahwa angka indeks persepsi kepuasan konsumen dari segi produk kopi dan pelayanan di Rumah Kopi Billy Cabang Megamas Manado berada pada titik $83.6 \%$ dan tergolong sangat puas. Rumah Kopi Billy Cabang Megamas Manado yang 
telah dikenal oleh masyarakat luas dengan produk kopinya yang mempunyai cita rasa yang nikmat dan khas. Persepsi kualitas yang tinggi menilaikualitas suatu produk berdasarkan berbagai informasiyang didapatnya baik melalui pengalaman menggunakan produk itu sendiri, atau dari penelitian yang dilakukan terhadap kepuasan Dari konsumen dari segi produk kopi, responden mengakui bahwa produk kopi Rumah Kopi Billy Cabang Megamas Manado memiliki pertukaran informasi dengan orang lain. variasi produk yang beragam. Selain itu, RKB menghindari penggunaan berulang. Cukup sekali pakai, karena penggunaan ampas kopi berulang akan mengurangi kenikmatan suatu cangkir kopi. Namun disamping itu, pelayanan yang akan suatu produk sangat berpengaruh terhadap tingkat kepuasan konsumen. Konsumen

diberikan merupakan faktor yang sangat berperan sebagai dasar konsumen untuk memilih produk yang ditawarkan. Penampilan, keramahan dan kesigapan karyawan dalam memberikan pelayanan kepada konsumen merupakan faktor kunci terhadap kesan yang akan dirasakan konsumen selama berada di Rumah Kopi Billy Cabang Megamas Manado. Selain itu ketepatan menu yang dipesan dan perlengkapan Rumah Kopi juga seringkali menjadi hal yang dipertimbangkan konsumen mengenai baik buruknya persepsi terhadap pelayanan yang dirasakan mereka.

Tabel 19. Rekapitulasi Total Skor, Indeks Kepuasan dan Interpretasi Nilai

\begin{tabular}{|c|c|c|c|c|}
\hline NO & PERNYATAAN & TOTAL SKOR & $\begin{array}{c}\text { INDEKS } \\
\text { KEPUASAN } \\
(\%)\end{array}$ & INTERPRETASI \\
\hline 1 & Variasi Produk Minuman Kopi & 200 & 80 & Puas \\
\hline 2 & Aroma Kopi & 201 & 80.4 & Puas \\
\hline 3 & Porsi Produk Kopi & 185 & 74 & Puas \\
\hline 4 & Higienitas Produk Kopi & 191 & 76,4 & Puas \\
\hline 5 & Cita Rasa dari Produk Kopi & 212 & 84,8 & Sangat Puas \\
\hline 6 & $\begin{array}{l}\text { Kecepatan Karyawan dalam } \\
\text { Penyajian Kopi yang di pesan }\end{array}$ & 210 & 84 & Sangat Puas \\
\hline 7 & $\begin{array}{l}\text { Kesigapan Karyawan dalam } \\
\text { Memberikan Pelayanan }\end{array}$ & 253 & 101,2 & Sangat Puas \\
\hline 8 & $\begin{array}{l}\text { Pengetahuan karyawan } \\
\text { terhadap produk kopi yang di } \\
\text { jual }\end{array}$ & 197 & 78.8 & Puas \\
\hline 9 & Penampilan fisik karyawan & 213 & 85.2 & Sangat Puas \\
\hline 10 & $\begin{array}{l}\text { Keramahan Karyawan dalam } \\
\text { Memberikan Pelayanan }\end{array}$ & 228 & 91.2 & Sangat Puas \\
\hline
\end{tabular}

Sumber: Diolah dari data primer, 2016 


\section{KESIMPULAN DAN SARAN}

\section{Kesimpulan Penelitian}

Proses pengukuran tingkat kepuasan konsumen dari segi produk kopi dan pelayanan mencapai total skor pengambilan data 2.090 yang menunjukan angka indeks pengukuran kepuasan konsumen sebesar $83.6 \%$ dan tergolong sangat puas. Hal ini menunjukan bahwa konsumen sangat puas dengan produk kopi yang ditawarkan dan pelayanan yang diberikan oleh karyawan di Rumah Kopi Billy Cabang Megamas Manado.

\section{Saran \\ Untuk meningkatkan kepuasan} konsumen dari segi produk dan pelayanan, maka pihak Rumah Kopi Billy Cabang Megamas Manado harus memperhatikan kualitas produk kopi dan kualitas pelayanan. Hal ini sangat penting, untuk mempertahankan konsumen dan mendapatkan konsumen lebih banyak serta meningkatkan penjualan.

\section{DAFTAR PUSTAKA}

Amstrong, Gary \& Philip, Kotler. 2002. Dasardasar Pemasaran. Jilid 1, Alih Bahasa

Alexander Sindoro dan Benyamin Molan. Jakarta: Penerbit Prenhalindo.

Augusty, Ferdinand. 2006. Metode Penelitian Manajemen. Semarang: Badan Penerbit Universitas Diponegoro.

Fandy, Tjiptono, Anastasia Diana, 2000, Total Quality Management, Edisi Revisi, Andiy Offset, Yogyakarta.

Fandy Tjiptono, 2004. Strategi Pemasaran, Edisi 2, Penerbit Andi, Yogyakarta.

Fandy Tjiptono, 2005. Pemasaran Jasa, Malang: Bayumedia Publishing.
Fandy Tjiptono, 2008. Strategi Bisnis Pemasaran. Andi. Yogyakarta.

Husein Umar, 2005. Metode Penelitian. Jakarta : Salemba Empat

Kotler, Philip dan Gary Amstrong, 1996, DasarDasar Pemasaran, Edisi V, jilid 2, Intermedia, Jakarta.

Kotler, P. 2000. Manajemen Pemasaran (Terjemahan, Jilid I dan II). PT. Elex Media Komputindo, Jakarta.

Kotler, Philip. 2005. Manajamen Pemasaran, Jilid 1 dan 2. Jakarta: PT. Indeks Kelompok Gramedia.

Kotler, Philip dan Gary Amstrong, 2008, Prinsip-prinsip Pemasaran, Jilid 1, Erlangga, Jakarta.

Mowen, John dan Michael Minor, 2002, Perilaku Konsumen, Jilid 1, Alih Bahasa Dwi Kartini Yahya, Erlangga, Jakarta.

Nasution, M. N. 2005. Manajemen Mutu Terpadu. Ghalia Indonesia, Bogor.

Oliver, Riscrd L, 1997. Satisfaction A Behavioral Perspective On The Consumer. McGraw-Hill Education, Singapore.

Parasuraman, A., V. A. Zeithaml, dan L.L. Berry, 1998, SERVQUAL: A MultipleItem Scale for Measuring Consumer Perceptions of Service Quality, Journal of Retailing, Vol. 64, No. 1.

Riduwan, 2008. Skala Pengukuran VariabelVariabel Penelitian. CV. Alfabeta

Riduwan, 2012. Metode \& Teknik Menyusun Proposal Penelitian. Bandung: Alfabeta

Sugiyono. 2004. Metode Penelitian Bisnis: Penerbit CV. Alfabeta: Bandung 